\title{
Reconstruction of hydrological changes based on tree-ring data of the Haba River, northwestern China
}

\author{
ZHANG Tongwen ${ }^{1,2,3^{*}}$, YUAN Yujiang ${ }^{1,2,3}$, CHEN Feng ${ }^{1,2,3}$, YU Shulong ${ }^{1,2,3}$, ZHANG \\ Ruibo $^{1,2,3}$, QIN Li ${ }^{1,2,3}$, JIANG Shengxia ${ }^{1,2,3}$ \\ ${ }^{1}$ Institute of Desert Meteorology, China Meteorological Administration, Urumqi 830002, China; \\ ${ }^{2}$ Key Laboratory of Tree-ring Physical and Chemical Research of China Meteorological Administration, Urumqi 830002, China; \\ ${ }^{3}$ Key Laboratory of Tree-ring Ecology of Xinjiang Uygur Autonomous Region, Urumqi 830002, China
}

\begin{abstract}
Reconstructing the hydrological change based on dendrohydrological data has important implications for understanding the dynamic distribution and evolution pattern of a given river. The widespread, long-living coniferous forests on the Altay Mountains provide a good example for carrying out the dendrohydrological studies. In this study, a regional composite tree-ring width chronology developed by Larix sibirica Ledeb. and Picea obovata Ledeb. was used to reconstruct a 301-year annual (from preceding July to succeeding June) streamflow for the Haba River, which originates in the southern Altay Mountains, Xinjiang, China. Results indicated that the reconstructed streamflow series and the observations were fitting well, and explained $47.5 \%$ of the variation in the observed streamflow of 1957-2008. Moreover, floods and droughts in 1949-2000 were precisely captured by the streamflow reconstruction. Based on the frequencies of the wettest/driest years and decades, we identified the $19^{\text {th }}$ century as the century with the largest occurrence of hydrological fluctuations for the last 300 years. After applying a 21-year moving average, we found five wet (1724-1758, 1780-1810, 1822-1853, 1931-1967, and 1986-2004) and four dry (1759-1779, 1811-1821, 1854-1930, and 1968-1985) periods in the streamflow reconstruction. Furthermore, four periods (1770-1796, 1816-1836, 1884-1949, and 1973-1997) identified by the streamflow series had an obvious increasing trend. The increasing trend of streamflow since the 1970s was the biggest in the last 300 years and coincided with the recent warming-wetting trend in northwestern China. A significant correlation between streamflow and precipitation in the Altay Mountains indicated that the streamflow reconstruction contained not only local, but also broad-scale, hydro-climatic signals. The 24-year, 12-year, and 2.2-4.5-year cycles of the reconstruction revealed that the streamflow variability of the Haba River may be influenced by solar activity and the atmosphere-ocean system.
\end{abstract}

Keywords: Larix sibirica Ledeb.; Picea obovata Ledeb.; streamflow reconstruction; tree-ring width; Altay Mountains

Citation: ZHANG Tongwen, YUAN Yujiang, CHEN Feng, YU Shulong, ZHANG Ruibo, QIN Li, JIANG Shengxia. 2018. Reconstruction of hydrological changes based on tree-ring data of the Haba River, northwestern China. Journal of Arid Land, 10(1): 53-67. https://doi.org/10.1007/s40333-017-0034-2

\section{Introduction}

Water is a crucial natural resource for providing sufficient food and a sustainable environment for

*Corresponding author: ZHANG Tongwen (E-mail: zhangtw@idm.cn)

Received 2016-10-10; revised 2017-11-14; accepted 2017-11-21

C Xinjiang Institute of Ecology and Geography, Chinese Academy of Sciences, Science Press and Springer-Verlag GmbH Germany, part of Springer Nature 2018 
the planet's human population and for other animals, plants, and microbes (Pimentel et al., 2004). Glacial retreat as a result of global warming and water consumption increases as results of economic development and population growth is exacerbating water stress in Central Asia (Yao et al., 2004; Siegfried et al., 2012). The management and control of water resources based on an understanding of the dynamic distribution and evolution pattern of a given river is one of the key approaches for addressing water shortages. However, most instrument-based hydrological records in Xinjiang, China, span less than 60 years. The short time period of the observed hydrological data does not adequately reflect the water resource and river streamflow patterns over a long-term period. To address this information gap, we used the tree-ring data to extend our knowledge of the hydroclimatic variability back hundreds of years for seasonal or annual timescales. Tree-ring data are one of the best sources of proxy streamflow information, because they allow precise dating, annual resolution, and comparability with recorded hydro-meteorological data (Pederson et al., 2001; Woodhouse, 2001; Polacek et al., 2006; Lara et al., 2008; Maxwell et al., 2011; Devineni et al., 2013; Shah et al., 2014).

The Haba River, originating in the Altay Mountains, is one of headstreams feeding the Irtysh River, which is the only river flowing to the Arctic Ocean in China. The widespread, long-living coniferous forest growing in the Altay Mountains provides a good example for carrying out dendrohydrological studies. Li et al. (1989) provided a 290-year length annual streamflow reconstruction for the Irtysh River based on tree-ring data. Compared with recent dendrohydrological studies (Gou et al., 2007; Yuan et al., 2007; Liu et al., 2010; Yang et al., 2011; Bao et al., 2012; Sun et al., 2013), there are deficiencies in existing methods used for streamflow reconstruction for the Irtysh River, such as limited sample depth, non-standard measurement, and simple stability tests. This study addresses these deficiencies by obtaining more reliable and accurate reconstruction using standard dendrochronological procedures. The aims of this study are to: (1) construct a tree-ring width based regional composite chronology from larch and spruce trees in the mountainous area of the Haba River, (2) reconstruct streamflow variations for the Haba River and explore the variations, and (3) assess regional climate signals inhering in the developed streamflow reconstruction.

\section{Materials and methods}

\subsection{Sample collection}

The Haba River has a length of $214.1 \mathrm{~km}$ and origins in the southern Altay Mountains $\left(47^{\circ} 52^{\prime}-49^{\circ} 09^{\prime} \mathrm{N}, 86^{\circ} 06^{\prime}-87^{\circ} 08^{\prime} \mathrm{E}\right.$; Fig. 1), Xinjiang, China. The average annual runoff of the Haba River is approximately $2.476 \times 10^{9} \mathrm{~m}^{3}$ and its drainage area covers $7224 \mathrm{~km}^{2}$. The study area has a temperate, continental climate. The annual average temperature is $4.7^{\circ} \mathrm{C}$, the annual total precipitation varies from 100 to $350 \mathrm{~mm}$, and the annual evaporation is $2010.3 \mathrm{~mm}$.

Two types of long-lived conifer, i.e., larch (Larix sibirica Ledeb.) and spruce (Picea obovata Ledeb.) were selected as our materials. The larch trees often grow up to $20 \mathrm{~m}$ high with elevations ranging from 1200 to $2600 \mathrm{~m}$ a.s.l., while these spruce trees often grow up to $35 \mathrm{~m}$ high with elevations ranging from 1200 to $1800 \mathrm{~m}$ a.s.1.. The forest stands are moderately open and the canopy densities are low. The soil type at the sampling sites is a Haplic Chernozems, which is thin and contains considerable amounts of gravel and rock (FAO et al., 2012). Subalpine shrubs and herbs, such as Vaccinium vitis-idaea L., Cotoneaster megalocarpus M. Pop, Lonicera altaica Pall, Pyrola rotundifolia L., Aconitum rotundifolium Kar et Kir., Poa supine Schrad., and Carex aneurocarpa V. Krecz., are scattered in the understory of the forests (Liu, 1997).

Information of the three sampling sites, i.e., Qibaakeshi (QBA), Maoyite (MYN) and Baolebadai (BLY), is shown in Table 1. To minimize non-climatic effects on tree growth, we selected healthy trees with little evidence of fire or human disturbance for sampling. For cross-dating purposes, two cores with different directions were extracted from selected trees, while only one core was extracted from younger trees. Overall, 161 cores from 84 living trees were collected at chest height from the three sites using increment borers (5.15 $\mathrm{mm}$ in diameter). 


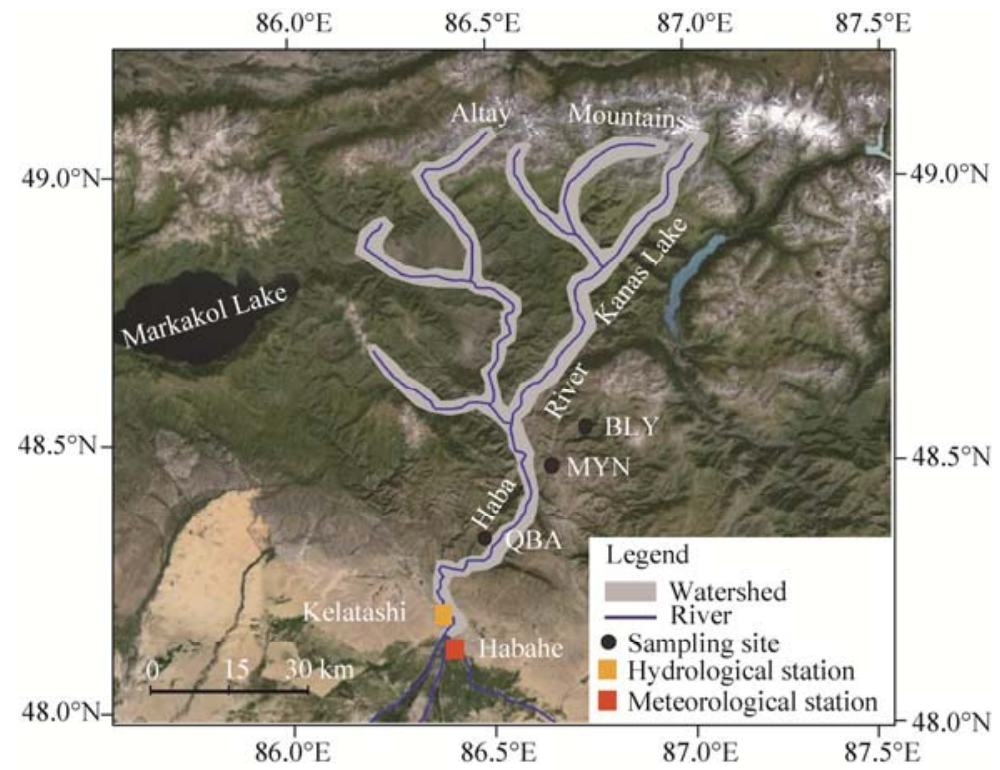

Fig. 1 Map of the Haba River watershed and sampling sites. QBA, Qibaakeshi; MYN, Maoyite; BLY, Baolebadai. Abbreviations are the same as in the following tables and figures.

Table 1 Information of the sampling sites in the Haba River

\begin{tabular}{|c|c|c|c|c|c|c|c|c|c|c|}
\hline Site & Latitude & Longitude & $\begin{array}{l}\text { Number of } \\
\text { trees/cores }\end{array}$ & $\begin{array}{l}\text { Elevation } \\
\text { (m) }\end{array}$ & Aspect & $\begin{array}{l}\text { Slope } \\
\left({ }^{\circ}\right)\end{array}$ & $\begin{array}{l}\text { Maximum } \\
\text { tree age (a) }\end{array}$ & $\begin{array}{l}\text { Percentage } \\
\text { of absent } \\
\text { rings }(\%)\end{array}$ & $\begin{array}{c}\text { Tree } \\
\text { species }\end{array}$ & $\begin{array}{c}\text { Date of } \\
\text { sampling } \\
\text { (yyyy-mm-dd) }\end{array}$ \\
\hline QBA & $48.42^{\circ} \mathrm{N}$ & $86.51^{\circ} \mathrm{E}$ & $32 / 58$ & 1700 & $\mathrm{~S}$ & 30 & $\begin{array}{c}405 \\
(1605-2009)\end{array}$ & 0.328 & $\begin{array}{c}\text { Larix } \\
\text { sibirica } \\
\text { Ledeb. }\end{array}$ & 2009-08-01 \\
\hline MYN & $48.46^{\circ} \mathrm{N}$ & $86.70^{\circ} \mathrm{E}$ & $26 / 52$ & 1150 & $\mathrm{~N}$ & 30 & $\begin{array}{c}303 \\
(1708-2010)\end{array}$ & 0.149 & $\begin{array}{l}\text { Picea } \\
\text { obovata } \\
\text { Ledeb. }\end{array}$ & $2010-07-15$ \\
\hline BLY & $48.49^{\circ} \mathrm{N}$ & $86.88^{\circ} \mathrm{E}$ & $26 / 51$ & 1650 & NW & 25 & $\begin{array}{c}305 \\
(1710-2014)\end{array}$ & 0.354 & $\begin{array}{l}\text { Picea } \\
\text { obovata } \\
\text { Ledeb. }\end{array}$ & 2014-08-20 \\
\hline
\end{tabular}

Note: QBA, Qibaakeshi; MYN, Maoyite; BLY, Baolebadai.

\subsection{Tree-ring width measurements and chronology development}

All the tree-ring cores were naturally dried, mounted, surfaced, and marked following standard dendrochronological procedures (Speer, 2010). Each tree-ring width was measured using a Velmex Measuring System with a resolution of $0.001 \mathrm{~mm}$ (Gou et al., 2007). Cross-dating quality control was performed using the COFECHA program (Grissino-Mayer, 2001). The ARSTAN program (Cook and Krusic, 2005) was used for detrending and developing tree-ring chronologies. The tree-ring width series were detrended with a negative exponential function (a conservative function) to remove non-climate signals related to tree age (Liu et al., 2010). For each tree-ring width series, the residual chronology was generated by removing the temporal autocorrelation using autoregressive moving average time-series models. The pooled model of autoregression was reincorporated into a residual chronology to develop an Arstan chronology containing the persistent, common, and synchronous signals among for a large proportion of the series from the sampled tree cores. Then, three types of chronologies from the sample sites were obtained (Cook and Kairiukstis, 1990). Generally, the sample depth within a chronology decreases further back in time. This could result in time-dependent variance changes in the earlier part of the chronology and a weaker common signal (Woodhouse, 2003). Therefore, the variance in the chronologies was stabilized in the chronology compilation process using the method outlined by Osborn et al. (1997). Their method uses average correlations of the series in combination with sample size for each year to adjust the variance of the changes in the sample size. Subsample signal strength (SSS) can be used to assess the adequacy of the replication in the early years of the chronology (Wigley 
et al., 1984). Therefore, to ensure our study focused only on the period of credible chronology, we restricted our analyses to the periods with a SSS of at least 0.85 .

\subsection{Hydro-meteorological data}

Monthly mean temperature and precipitation data for 1958-2014 were obtained from the Habahe Meteorological Station $\left(48.05^{\circ} \mathrm{N}, 86.40^{\circ} \mathrm{E} ; 534 \mathrm{~m}\right.$ a.s.l.) near three sampling sites. Climatic data were obtained from the China Meteorological Data Service Center (CMDC, http://cdc.cma.gov.cn/). Monthly streamflow data for 1956-2008 were obtained from the Kelatashi Hydrological Gauging Station $\left(48.22^{\circ} \mathrm{N}, 86.42^{\circ} \mathrm{E} ; 590 \mathrm{~m}\right.$ a.s.1.), which is located in the mountain-pass of the Haba River watershed. These hydrological data were provided by the Hydrological and Water Resources Bureau of Xinjiang. Figure 2a shows that the highest temperatures occur in summer (June-August) and that the highest mean temperature occurs in July $\left(22.1{ }^{\circ} \mathrm{C}\right)$. A major proportion of the total annual precipitation falls during May-July, although there are peaks in both July $(21.8 \mathrm{~mm})$ and November $(21.4 \mathrm{~mm})$. Much less precipitation falls in winter. The climate data recorded in the study area since 1958 show that there are significant increasing trends occurring in both temperature $(P<0.001)$ and precipitation $(P<0.01)$ (Figs. 2b and c). Figure 2d reveals that streamflow from June to August comprises a major proportion of the annual total runoff and peaks in June $\left(204.6 \mathrm{~m}^{3} / \mathrm{s}\right)$. The annual streamflow fluctuates around the mean value, and the decreasing trend during the period 1956-2008 is not significant (Fig. 2e). The correlation coefficients between annual streamflow and annual total precipitation $(r=0.599, P<0.001, n=51)$, and between annual streamflow and annual mean temperature $(r=-0.356, P<0.01, n=51)$ exceed significance level.
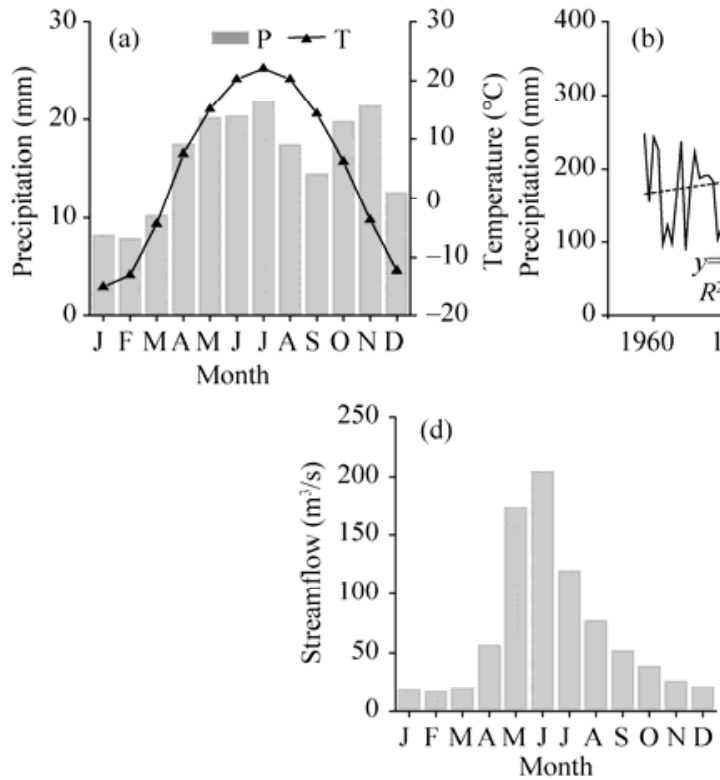

(b)
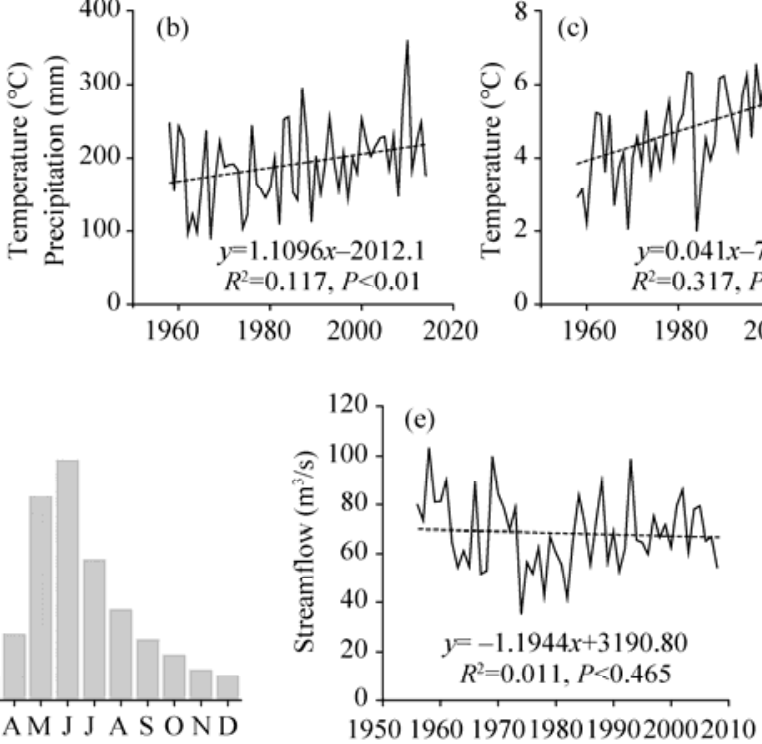

Fig. 2 Meteorological data and streamflow data of the Haba River. (a) Monthly precipitation (P) and monthly mean temperature (T); (b) Annual precipitation during 1958-2014; (c) Annual mean temperature during 1958-2014; (d) Monthly streamflow; (e) Annual streamflow during 1956-2008.

\subsection{Statistical analysis}

The developed tree-ring chronologies were decomposed into high- and low-pass components using 13 years reciprocal filters to assess the variation patterns in different frequency domains (Yuan et al., 2013). The weights of the filters are calculated by the reciprocal filters described by Fritts (1976). Pearson's correlation coefficients were used to quantify the strengths of tree growth climate response and climatic and hydrological signals contained in the radial growth of trees. After confirming the strongest seasonal relationship between tree-ring width and observed data, we used a linear regression model for the reconstruction. Because the length of the 
instrumental-based records is relatively short for the independent sub-period calibration and verification tests, we used the methods of Bootstrap (Young, 1994) and Leave-one-out cross validation (LOOCV) (Michaelsen, 1987) to evaluate the statistical reliability of the reconstruction model. In the LOOCV analysis, several statistical procedures, including coefficient of efficiency, sign test, and product mean test were used to evaluate the coherence between the observed and estimated data (Cook et al., 1999). Power spectrum analysis was applied to examine sensible periodicities in our reconstruction (Fritts, 1976). Wavelet analysis was used with a Morlet wavelet to investigate the periodicity of the reconstructed series and to examine how this periodicity changed over time (http://climexp.knmi.nl). Spatial correlation was used to identify coherence between our reconstruction and the gridded $0.5^{\circ} \times 0.5^{\circ}$ Climatic Research Unit (CRU) self-calibrating Palmer Drought Severity Index (PDSI) 3.21 dataset (Wells et al., 2004) in a large region using the Royal Netherlands Meteorological Institute (KNMI) Climate Explorer.

\section{Results and discussion}

\subsection{Statistical characteristics of the tree-ring width chronologies and the development of a regional composite chronology}

For further analysis, we used the standard chronologies that contained the common variations among the individual tree-core series and retained a high-frequency common variance. This variance is presumably in response to climate (Cook, 1985). Because of the low correlations with the master dating series, 4 cores (from 3 trees) in the QBA site, 1 core (from 1 tree) in the MYN site, and 1 core (from 1 tree) in the BLY site were rejected. Ultimately, 54 cores (from 31 trees) in the QBA site, 51 cores (from 26 trees) in the MYN site, and 50 cores (from 25 trees) in the BLY site were used to develop ring-width chronologies. Three tree-ring width chronologies with their sample depths are shown in Figure 3, and the general statistics of the description of the chronologies for a common period analysis from 1900 to 1999 are listed in Table 2.

The standard deviation (SD) estimates the variability of measurements for the whole series, and the mean sensitivity (MS) is an indicator of the relative change in ring-width variance between
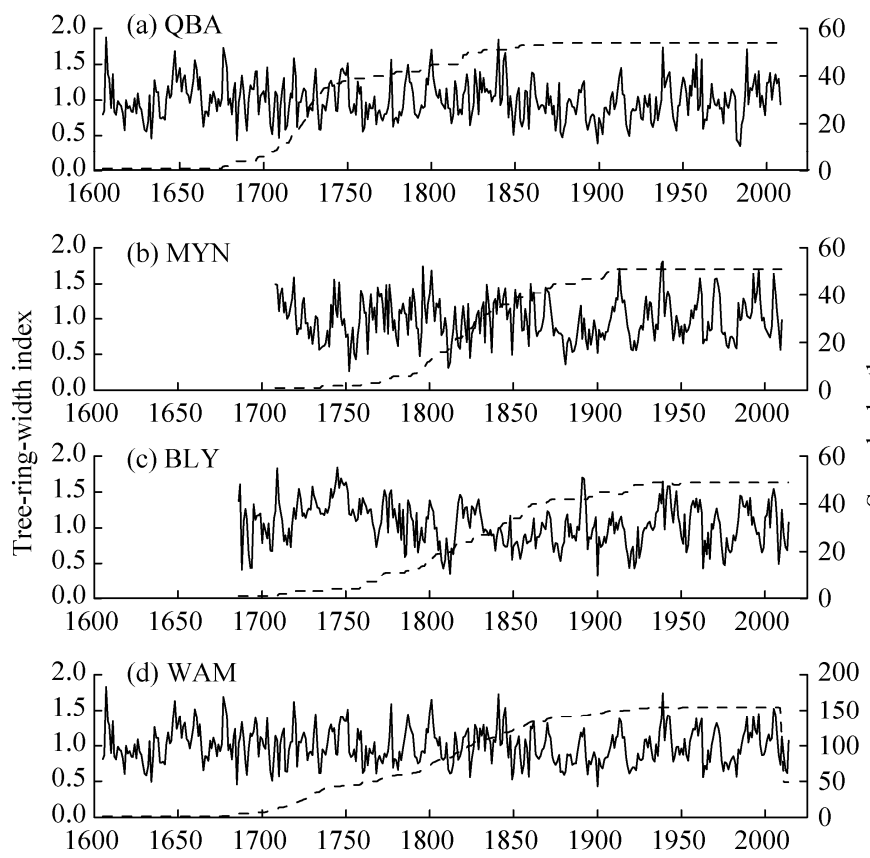

Fig. 3 Three tree-ring width chronologies (QBA, MYN, and BLY) and one regional ring-width composite chronology (WAM) and their sample depths. Solid lines represent the tree-ring width indices and dashed lines indicate the sample depths. 
Table 2 Statistical characteristics of tree-ring chronologies during 1900-1999

\begin{tabular}{lcccc}
\hline Statistic & QBA & MYN & BLY & WAM \\
\hline Standard deviation (SD) & 0.271 & 0.299 & 0.297 & 0.250 \\
Mean sensitivity (MS) & 0.214 & 0.240 & 0.197 & 0.188 \\
First-order autocorrelation (AC1) & 0.459 & 0.505 & 0.636 & 0.513 \\
Interseries correlation (trees) & 0.360 & 0.508 & 0.256 & 0.245 \\
Interseries correlation (all series) & 0.365 & 0.515 & 0.266 & 0.249 \\
Mean within-tree correlation & 0.541 & 0.811 & 0.749 & 0.658 \\
Signal-to-noise ratio (SNR) & 31.091 & 49.877 & 15.621 & 47.623 \\
Expressed population signal (EPS) & 0.969 & 0.980 & 0.940 & 0.979 \\
First year SSS $>0.85$ (core number) & $1704(8)$ & $1773(5)$ & $1773(11)$ & $1714(15)$ \\
\hline Note: SSS, subsample signal strength; WAM, regional ring-width composite chronology. & &
\end{tabular}

Note: SSS, subsample signal strength; WAM, regional ring-width composite chronology.

consecutive years (Fritts, 1976). Values of SD and MS for the chronologies obtained using the regional ring-width composite chronology (WAM) as a result of the combination of tree-ring samples are slightly lower than those of the chronologies for a single sample site. The first-order autocorrelation (AC1) assesses relationships with previous growth. These values range from 0.459 to 0.636 , which shows that the chronologies contain low-frequency variance generated by climate and by tree-physiological lag effects. The interseries correlations of the WAM are also relatively lower as a result of the increase in sample depth from the three sampling sites. The value of SSS exceeded 0.85 , revealing that the threshold corresponds to a minimum sample depth of 15 cores for the WAM. Thus, a credible time span for the regional composite chronology is 301 years (1714-2014).

After applying the 13-year reciprocal filters, Pearson's correlation analysis was performed on the three sets of data, i.e., the original unfiltered, high-pass filtered, and low-pass filtered data. As shown in Table 3, there were significant correlations among the three sampling sites in the original, high-, and low-frequency domains over the period 1773-2009. Therefore, we decided to combine all the raw tree-ring width data from the three sampling sites (QBA, MYN, and BLY) to develop a longer and better-replicated WAM. This was developed using the methods described in the above section (tree-ring width measurements and chronology developments). The newly-developed regional ring-width composite chronology and its sample depths are shown in Figure 3, and the general descriptive statistics were listed in Table 2.

Table 3 Correlation coefficients among the three sampling sites in original, high-, and low-frequency domains during 1773-2009

\begin{tabular}{|c|c|c|c|c|c|c|c|c|c|}
\hline & \multicolumn{3}{|c|}{ Original domain $(n=237)$} & \multicolumn{3}{|c|}{ High-frequency domain $(n=225)$} & \multicolumn{3}{|c|}{ Low-frequency domain $(n=225)$} \\
\hline & QBA & MYN & BLY & QBA & MYN & BLY & QBA & MYN & BLY \\
\hline QBA & 1.000 & $0.431^{*}$ & $0.319^{*}$ & 1.000 & $0.250^{*}$ & $0.273^{*}$ & 1.000 & $0.599^{*}$ & $0.363^{*}$ \\
\hline MYN & & 1.000 & $0.382^{*}$ & & 1.000 & $0.257^{*}$ & & 1.000 & $0.378^{*}$ \\
\hline BLY & & & 1.000 & & & 1.000 & & & 1.000 \\
\hline
\end{tabular}

Note: ${ }^{*}$ indicates the significance at $P<0.01$ level.

\subsection{Correlation analysis}

A strong biological lag effect was indicated by the high AC1 values for the chronologies from single and composite sites ranging from 0.459 to 0.636 (Table 2). Therefore, the monthly precipitation (1958-2014), monthly mean temperature (1958-2014), and monthly streamflow data (1956-2008) from preceding July to succeeding October were used to assess the effects of climatic and hydrological factors on the radial growth of coniferous trees in the study area. As can be seen from Figure 4, the results of the correlation indicated that the relationship between tree-ring width and precipitation was positive in general, and that a significant correlation coefficient was found in preceding July $(r=0.411, P<0.01, n=56)$. However, the response between 
the radial growth of coniferous trees and temperature was negative, and the WAM was negatively correlated with the mean temperature of succeeding June $(r=-0.475, n=57)$, July $(r=-0.291$, $n=57)$, and August $(r=-0.262, n=57)$ at the $95 \%$ confidence level. After testing different combinations of months, the highest correlation coefficient between the WAM and the precipitation was found for the period from preceding April to preceding September $(r=0.445$, $P<0.001, n=56$ ); however, the regional composite chronology and mean temperature in succeeding June still had the strongest relationship. The monthly streamflow from preceding July to succeeding October were also tested for correlations with the regional composite chronology. Significant correlations were found from preceding July to succeeding September (except October) based on the 95\% confidence level, peaking in preceding September, and succeeding February. After combination, the highest correlation coefficient between the WAM and July-June streamflow was obtained $(r=0.690, P<0.001, n=52)$. Our results show that the influence of streamflow on tree-ring growth in the study area is similar to that found in previous dendroclimatic studies for North China, such as Picea schrenkiana in the Manas River watershed (Yuan et al., 2007), Sabina przewalskii in the Heihe River watershed (Liu et al., 2010; Yang et al., 2011), Juniperus przewalski in the Yellow River watershed (Gou et al., 2007), and Pinus sylvestris var. mongolica in the Yimin River watershed (Bao et al., 2012).
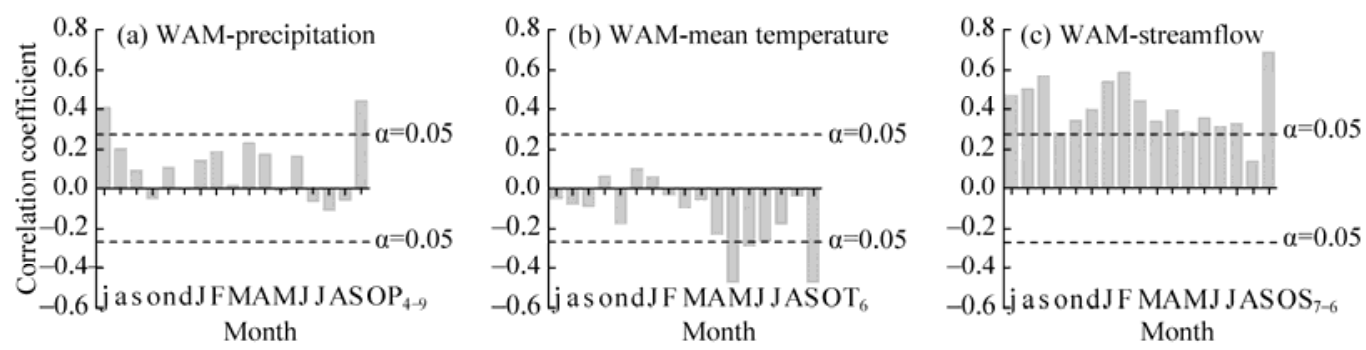

Fig. 4 Pearson's correlations of the WAM and precipitation (a) and mean temperature (b) from the Haba River station and the streamflow (c) from the Kelatashi station. Lowercase letters represent months of preceding year, and uppercase letters are months of succeeding year. $\mathrm{P}_{4-9}$ indicates precipitation from April to September. $\mathrm{T}_{6}$ indicates mean temperature in June, and $\mathrm{S}_{7-6}$ indicates streamflow from preceding July to succeeding June. Dashed lines indicate the 0.05 significance levels.

\subsection{Streamflow reconstruction and stability tests}

We computed the correlation coefficients between the radial growth of larch and spruce trees within the study area and various assemblages of months of streamflow for the period 1957-2008 to determine the appropriate season for reconstruction. To do this, we reconstructed the streamflow from preceding July to succeeding June using the regional composite chronology. A linear regression model was used to describe the relationship between the tree-ring chronology and streamflow. The model was as follows:

$$
S_{7-6}=31.081+36.149 \times \text { WAM, }
$$

where $S_{7-6}$ is the streamflow from preceding July to succeeding June for the Haba River $\left(\mathrm{m}^{3} / \mathrm{s}\right)$ and WAM is the regional tree-ring width composite chronology. The model accounts for $47.5 \%$ (46.5\% after adjusting for loss of degrees of freedom) of the gauged streamflow variance during the calibration period 1957-2008 for the WAM. Figure 5a shows that the reconstructed July-June streamflow and the observations are well fitting, including the clear low-frequency changes. We further compared the first differences (year-to-year changes) of the reconstruction and the observations, and obtained a correlation coefficient of 0.595 ( $P<0.0001, n=51$; Fig. 5b).

The results of the Bootstrap test (100 iterations in the recomputation process) show that all values of $r, R^{2}, R^{2}$ adj, standard error (SE), $F$-value $(F), P$, and Durbin-Watson (DW) are close to those of the original regression model 1 (Table 4). Furthermore, the resulting statistics of LOOCV are shown in Table 4 (Cook et al., 1999). The results of the low-frequency sign test $\left(\mathrm{S}_{1}\right)$ and the high-frequency sign test $\left(\mathrm{S}_{2}\right)$, which describe how well the predicted value tracks the direction of the actual data, all exceed the 0.01 significant level. The coefficient of efficiency exceeds 0 . The values of the product mean test $(t)$ are positive, which indicates significant accuracy in the 
tree-ring estimations (Fritts, 1976). These test results all demonstrate that model 1 is stable and reliable and that it could be used for streamflow reconstruction. Consequently, we reconstructed the Haba River streamflow from preceding July to succeeding June during the period 1714-2014 based on model 1, resulting in a mean of $66.74 \mathrm{~m}^{3} / \mathrm{s}$ and a standard deviation of $\sigma=8.89 \mathrm{~m}^{3} / \mathrm{s}$ (Fig. 5c).
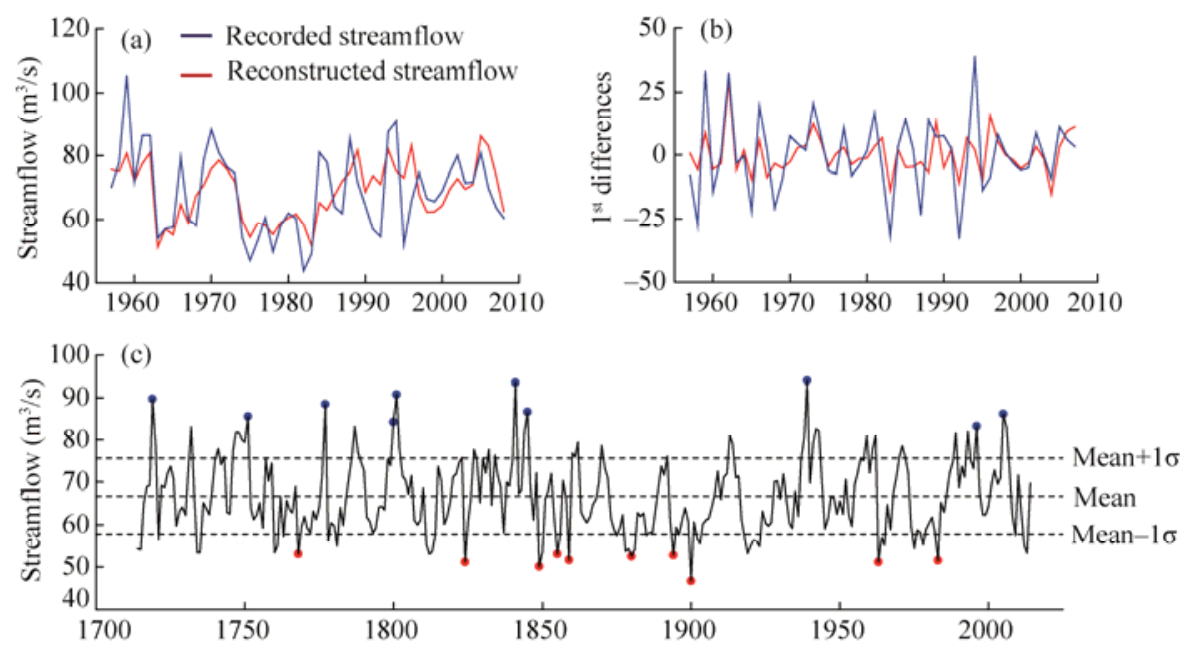

Fig. 5 (a) Comparison between the recorded (blue line) and reconstructed (red line) July-June streamflow for the Haba River. (b) Comparison between the first differences (year-to-year changes) of the recorded (blue line) and reconstructed (red line) July-June streamflow series. (c) July-June streamflow reconstruction for the Haba River since 1714 (solid line). The dashed horizontal lines represent the long-term mean for the period 1714-2014 and the mean value $\pm 1 \sigma$. Blue and red dots indicate the wettest and driest years, respectively.

Table 4 Verification results from the Bootstrap and Leave-one-out tests for streamflow reconstruction for the Haba River

\begin{tabular}{|c|c|c|c|c|}
\hline Statistic & Calibration & $\begin{array}{c}\text { Bootstrap (100 iterations) } \\
\text { mean (ranges) }\end{array}$ & Statistic & $\begin{array}{l}\text { Leave-one-out cross } \\
\text { validation (LOOCV) }\end{array}$ \\
\hline$r$ & 0.690 & $0.692(0.525-0.879)$ & \multirow{2}{*}{$\begin{array}{l}\text { Low-frequency } \\
\text { sign test }\left(\mathrm{S}_{1}\right)\end{array}$} & \multirow[b]{2}{*}{$40+/ 12-(P<0.01)$} \\
\hline $\begin{array}{l}\text { Squared multiple } \\
\text { correlation }\left(R^{2}\right)\end{array}$ & 0.475 & $0.484(0.275-0.773)$ & & \\
\hline $\begin{array}{l}\text { Adjusted squared multiple } \\
\text { correlation }\left(R^{2}{ }_{\text {adj }}\right)\end{array}$ & 0.465 & $0.474(0.258-0.767)$ & \multirow{2}{*}{$\begin{array}{l}\text { High-frequency } \\
\text { sign test }\left(\mathrm{S}_{2}\right)\end{array}$} & \multirow[t]{2}{*}{$37+/ 14-(P<0.01)$} \\
\hline Standard error (SE) & 9.599 & $9.332(6.172-12.362)$ & & \\
\hline$F$-value $(F)$ & 45.318 & $51.132(13.535-142.179)$ & \multirow{2}{*}{$\begin{array}{l}\text { Product mean } \\
\text { test }(\mathrm{t})\end{array}$} & \multirow{2}{*}{8.25} \\
\hline$P$ & 0.001 & $0.001(0.001-0.001)$ & & \\
\hline Durbin-Watson (DW) & 1.583 & $1.222(0.552-1.953)$ & $\begin{array}{l}\text { Coefficient of } \\
\text { efficiency (CE) }\end{array}$ & 0.43 \\
\hline
\end{tabular}

\subsection{Characteristics of the streamflow reconstruction}

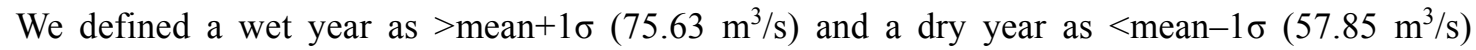
according to the method of division used by Liu et al. (2014). The newly reconstructed July-June streamflow series revealed that 51 years could be categorized as 'wet years' (accounting for $16.9 \%$ of the total), 47 years categorized as 'dry years' (accounting for $15.6 \%$ of the total), and the remaining 203 years categorized as 'normal years' (accounting for $67.5 \%$ of the total). The values for extreme years and the means of the extreme decades are listed in Table 5. It can be seen that the difference between the wettest (1939) and driest (1900) years is $47.36 \mathrm{~m}^{3} / \mathrm{s}$, and that the difference between the wettest and driest decades (1740s and $1880 \mathrm{~s}$, respectively) is $14.99 \mathrm{~m}^{3} / \mathrm{s}$.

Table 5 also shows the long-term means and variation coefficients (Bai et al., 2014) for the streamflow reconstruction. The results demonstrate that streamflow in the Haba River was 
comparatively abundant in the $18^{\text {th }}$ century, and that an obvious decrease in streamflow occurred in the $19^{\text {th }}$ century. Thereafter, the streamflow series start to increase and reach a peak in the early $21^{\text {st }}$ century. The variation coefficient for the $19^{\text {th }}$ century was slightly higher than any other of the last 300 years. In addition, the number of anomalies in the $19^{\text {th }}$ century, including the 4 wettest and 6 driest years, and the 3 wettest and 5 driest decades, was greater than in any other of the last 300 years. These findings are consistent with those from a 305-year long early summer temperature reconstruction for the southern Altay Mountains (Zhang et al., 2015), which demonstrated that there was a greater climatic fluctuation in the $19^{\text {th }}$ century, based on the number of extreme years and decades, than in the other two centuries.

Table 5 Summary of streamflow reconstruction characteristics for the Haba River

\begin{tabular}{|c|c|c|c|c|c|c|c|c|c|c|}
\hline \multicolumn{2}{|c|}{10 wettest years } & \multicolumn{2}{|c|}{10 driest years } & \multicolumn{2}{|c|}{10 wettest decades } & \multicolumn{2}{|c|}{10 driest decades } & \multicolumn{3}{|c|}{ Long-term trend } \\
\hline Year & $\begin{array}{l}\text { Value } \\
\left(\mathrm{m}^{3} / \mathrm{s}\right)\end{array}$ & Year & $\begin{array}{l}\text { Value } \\
\left(\mathrm{m}^{3} / \mathrm{s}\right)\end{array}$ & Decade & $\begin{array}{l}\text { Mean } \\
\left(\mathrm{m}^{3} / \mathrm{s}\right)\end{array}$ & Decade & $\begin{array}{l}\text { Mean } \\
\left(\mathrm{m}^{3} / \mathrm{s}\right)\end{array}$ & Years & $\begin{array}{l}\text { Mean } \\
\left(\mathrm{m}^{3} / \mathrm{s}\right)\end{array}$ & Variation coefficient \\
\hline 1939 & 94.02 & 1900 & 46.66 & $1740 \mathrm{~s}$ & 74.99 & $1880 \mathrm{~s}$ & 60.00 & $1714-1799$ & 67.08 & 0.131 \\
\hline 1841 & 93.55 & 1849 & 50.13 & $1840 \mathrm{~s}$ & 72.55 & $1760 \mathrm{~s}$ & 60.61 & $1800-1899$ & 66.24 & 0.136 \\
\hline 1801 & 90.80 & 1824 & 51.18 & $1990 \mathrm{~s}$ & 71.99 & $1920 \mathrm{~s}$ & 60.67 & 1900-1999 & 66.74 & 0.134 \\
\hline 1719 & 89.68 & 1963 & 51.18 & $1800 \mathrm{~s}$ & 71.56 & $1900 \mathrm{~s}$ & 60.70 & 2000-2014 & 68.17 & 0.132 \\
\hline 1777 & 88.49 & 1983 & 51.54 & $2000 \mathrm{~s}$ & 71.05 & $1810 \mathrm{~s}$ & 61.93 & $1714-2014$ & 66.74 & 0.133 \\
\hline 1845 & 86.68 & 1859 & 51.58 & $1830 \mathrm{~s}$ & 70.44 & $1850 \mathrm{~s}$ & 62.02 & & & \\
\hline 2005 & 86.21 & 1880 & 52.45 & $1930 \mathrm{~s}$ & 70.39 & $1870 \mathrm{~s}$ & 63.06 & & & \\
\hline 1751 & 85.63 & 1894 & 52.73 & $1940 \mathrm{~s}$ & 69.95 & $1890 \mathrm{~s}$ & 63.87 & & & \\
\hline 1800 & 84.29 & 1855 & 53.02 & $1750 \mathrm{~s}$ & 69.77 & $1770 \mathrm{~s}$ & 64.46 & & & \\
\hline 1996 & 83.35 & 1768 & 53.06 & $1950 \mathrm{~s}$ & 69.39 & $1970 \mathrm{~s}$ & 64.74 & & & \\
\hline
\end{tabular}

Unlike the detailed historical documents from southern China, the records regarding meteorological disasters in Xinjiang, China, are sporadic and limited as a result of the historically low level of human activity. Historical records regarding weather-induced disaster for the Haba River watershed are also extremely limited. After the founding of the People's Republic of China (1949), many meteorological stations were established and normal observations were carried out. These records allow one of the ten wettest years (1996) and two of the ten driest years (1963 and 1983) in our hydrologic reconstruction to be compared with the meteorological records for the period 1949-2000 (Wen et al., 2006). The results show a good agreement between our reconstruction, meteorological records, and meteorological descriptions based on these records (Table 6). Furthermore, there are 1776 and 1900 as the extremely wet and dry years respectively finding in the streamflow reconstruction for the upper Irtysh River (Chen et al., 2016) and precipitation reconstruction for the southern Altay Mountains (Chen et al., 2014). A very severe drought period during the 1920s occurring in a wide area of northern China is mentioned in historical records (Shi et al., 1991) and tree-ring based hydro-climatic reconstructions (Liang et al., 2006; Gou et al., 2007). This consistent drought is also recorded as the third driest decades in the Haba River streamflow series (Table 5). Thus, our reconstructed hydrological series can capture the signals of flood or drought disasters for the Haba River watershed.

\subsection{Linkages to the recent warming-wetting trend}

The decadal variability was highlighted by applying a 21-year moving average to the reconstruction, as shown in Figure 6, from which five wet and four dry periods can be distinguished. The wet periods (above the mean value of the reconstruction) were 1724-1758 (average value: $\left.69.03 \mathrm{~m}^{3} / \mathrm{s}\right), 1780-1810\left(68.09 \mathrm{~m}^{3} / \mathrm{s}\right), 1822-1853\left(69.50 \mathrm{~m}^{3} / \mathrm{s}\right), 1931-1967(69.11$ $\left.\mathrm{m}^{3} / \mathrm{s}\right)$, and 1986-2004 $\left(70.24 \mathrm{~m}^{3} / \mathrm{s}\right)$. The dry periods (below the mean) were 1759-1779 $\left(63.67 \mathrm{~m}^{3} / \mathrm{s}\right), 1811-1821\left(65.16 \mathrm{~m}^{3} / \mathrm{s}\right), 1854-1930\left(63.49 \mathrm{~m}^{3} / \mathrm{s}\right)$, and $1968-1985\left(64.65 \mathrm{~m}^{3} / \mathrm{s}\right)$. Figure 6 reveals that there were 4 periods, i.e., 1770-1796 (lasting for 27 years), 1816-1836 (21 years), 1884-1949 (66 years), and 1973-1997 (25 years) with an increasing trend existing in the 
streamflow reconstruction in the low-frequency domain.

Table 6 Wettest and driest years of in the hydrological reconstruction of the Haba River watershed in comparison with meteorological records for the period 1949-2000

\begin{tabular}{|c|c|c|}
\hline Type & Year & Short description of flood or drought disaster \\
\hline \multirow{3}{*}{ Wettest year } & \multirow{3}{*}{1996} & 1. Some floods occurred in the Altay region in July and August, 1995. \\
\hline & & 2. Some floods occurred in the Altay region in June, July, August, and September, 1996. \\
\hline & & 1. Great drought occurred in the whole Xinjiang in 1962 . There was $50 \%$ streamflow of the Altay \\
\hline \multirow{4}{*}{ Driest year } & 1963 & $\begin{array}{l}\text { River, and the streamflow of the Burqin River reduced } 40 \% \text {. People and livestock lacked adequate } \\
\text { drinking water. }\end{array}$ \\
\hline & & $\begin{array}{l}\text { 2. Drought occurred in the Altay, Tacheng, and Ili regions in 1963. Less rain and snow in spring } \\
\text { led to drought in the Altay region. }\end{array}$ \\
\hline & & $\begin{array}{l}\text { 1. Drought occurred in the Altay, Tacheng, Ili, and Karamay regions in } 1982 \text {. There was } 10 \% \\
\text { production reduction in the irrigated land, while there was no harvest in dry land in the Burqin } \\
\text { region. }\end{array}$ \\
\hline & 1983 & $\begin{array}{l}\text { 2. Infrequent drought occurred in the whole Xinjiang in 1983. Extraordinary drought occurred } \\
\text { due to the rare snow in winter and less rain in the following season in the Burqin region. The } \\
\text { streamflow of the Burqin River was } 13 \mathrm{~m}^{3} / \mathrm{s} \text { in April, and the streamflow of the Irtysh River was } \\
\text { only } 0.5 \mathrm{~m}^{3} / \mathrm{s} \text { on } 3 \text { May. }\end{array}$ \\
\hline
\end{tabular}

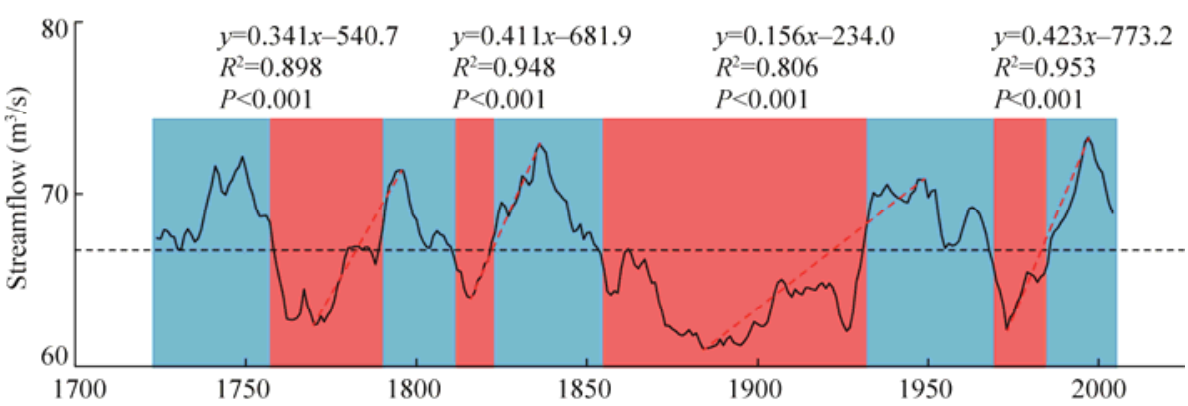

Fig. 6 Variations in the streamflow reconstruction for the low-frequency domain. The black line shows data smoothed with a 21-year low-pass filter to reflect the long-term fluctuations. The red dashed lines represent trend lines for the periods with increasing streamflow. The horizontal dashed line represents the long-term mean for the period 1714-2014. The blue bars indicate the wet periods; the red bars indicate the dry periods.

Generally, more precipitation leads to more streamflow as a result of increased runoff, while higher temperatures lead to less streamflow because of stronger evaporation. However, rivers in the arid and semi-arid areas may have large streamflow despite increasing temperature (Chen and Wang, 2004). Based on daily meteorological data, Li and Jiang (2007) found that an abrupt change in precipitation occurred (from less to more) over northern Xinjiang in 1984. A warming trend since the 1980s has frequently been observed in records obtained from instrument-based monitoring (Li et al., 2006). Shi et al. (2007) also indicated that since 1987, the climate has changed from the warm-dry to the warm-wet in Xinjiang, China. As a result of the higher coefficient of $X$ and $R^{2}$ in the tendency equation, the increasing trend from 1973 to 1997 in the newly reconstructed streamflow series for the Haba River changed more dramatically than at any other time in the last 300 years. The results confirmed that the streamflow of the Haba River, and other small drainage basins in the Xinjiang, had an obvious increasing trend in response to the recent warming-wetting trend in northwestern China.

\subsection{Regional/large-scale climate signals inhering in the streamflow reconstruction}

Dai et al. (2004) revealed that basin-averaged annual PDSI covaried closely with streamflow for seven of the world's largest rivers and several smaller rivers. Thus, PDSI can be regarded as a good proxy of both surface moisture conditions and streamflow. A significant correlation $(r=0.583$, $P<0.01)$ was found between a 251-year long drought reconstruction for the northern Altay Mountains and the annual streamflow for the Irtysh River (Chen et al., 2015). The spatial correlation was applied to evaluate the regional significance of tree-ring width based streamflow reconstruction. The streamflow reconstruction correlates (coefficient $>0.5$ ) with the gridded July-June PDSI data for 1956-2012 in a large area between approximately $43^{\circ}-51^{\circ} \mathrm{N}$ and 
$79^{\circ}-90^{\circ} \mathrm{E}$, with the highest correlations (coefficient $>0.6$ ) occurring in the northern Junggar Basin and the entire Altay Mountains (Fig. 7).

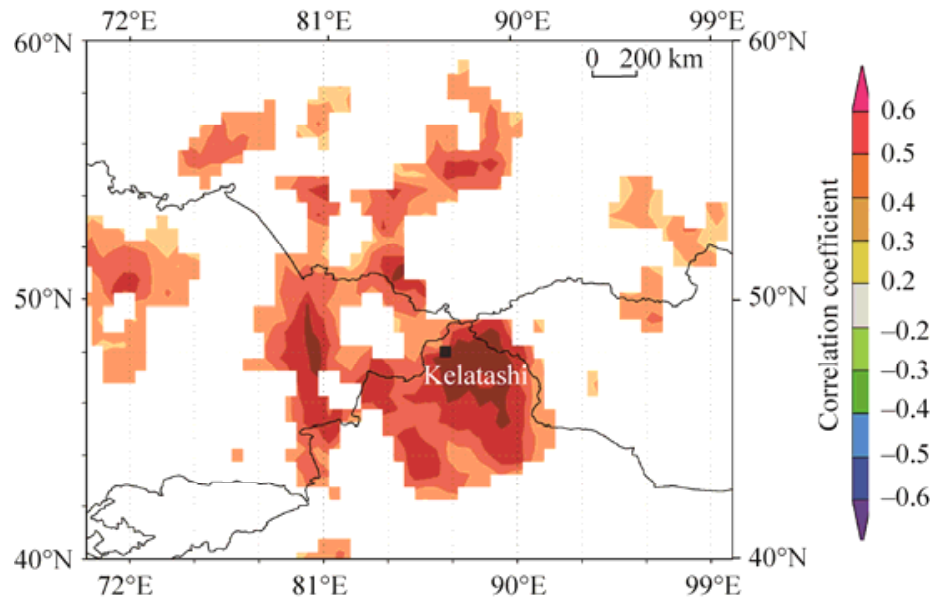

Fig. 7 Spatial correlation of the streamflow reconstruction for the Haba River with the gridded Palmer Drought Severity Index dataset

The correlations between the tree-ring width chronologies in the study area and precipitation were not high. However, the streamflow reconstructions in the previous studies are limited. Therefore, a July-June precipitation reconstruction for the Altay Mountains (an explained variance of $65.5 \%$; Chen et al., 2014) was selected to examine whether there is a connection between our reconstruction and other reconstructions. The correlation coefficient for the streamflow reconstruction and the precipitation reconstruction is $0.54(P<0.0001, n=185)$. After employing a 13-year reciprocal filter, both the tree-ring width based reconstructions were decomposed into high- and low-pass components for comparison. The correlation coefficients in the high- and low-frequency domains are 0.44 and 0.59 , respectively. Figure 8 a shows that the streamflow reconstruction and the precipitation reconstruction corresponded well during the period 1825-2009. Furthermore, most of the high and low values in the two reconstructions appeared in similar years in the high-frequency domain (Fig. 8b). In addition, the variation modes and long-term trends of two reconstructions were roughly synchronous in the low-frequency domain (Fig. 8c). These results confirmed that broad-scale regional climatic elements could affect the streamflow variations of the Haba River.

The results of the power spectral analysis over the entire reconstruction period (1714-2014) revealed that significant periodicity is further indicated at a frequency of 4.5-year (90\%), 3.2-year $(95 \%)$, and 2.2-year (90\%; Fig. 9a). The temporal characteristics of the different cycles were also evaluated using wavelet analysis and are illustrated in Figure 9b. The wavelet analysis indicates a robust approximate 24-year cycle from 1880 to 1950. In contrast, a significant (although less robust) power with an approximate 12-year cycle is detected from 1780 to 1810 and from 1940 to 1980. The 12-year cycle in our reconstructed streamflow series suggested a possible important connection with the 11-year Schwabe cycle of solar activity (Nagovitsyn, 1997). The 24-year cycle roughly corresponded to the 22-year Hale cycle - the double harmonics of the 11-year cycle. The inter-annual cycles (4.5-year and 3.2-year) in our reconstruction fall within the range of the El Niño-Southern Oscillation (ENSO) (Allan et al., 1996). Luo (2005) also indicated that there is an approximate 3-year cycle appearing in the precipitation variability for the northwestern China. Furthermore, the above cycles contained in the streamflow reconstruction for the Haba River can often be found in earlier dendroclimatic studies of the Altay Mountains. The 11-year and 2-year cycles contained in the 310-year early summer temperature series for northeastern Kazakhstan have been examined using power spectral analysis by Shang et al. (2011). Zhang et al. (2015) identified the frequencies of 11-year and 2.0-2.7-year cycles in a summer precipitation reconstruction of the southern slope of the Altay Mountains recorded using tree-ring $\delta^{13} \mathrm{C}$. Jiang et 
al. (2016) also revealed that there were 24.3-year, 3.2-year, and 2.1-year cycles in the July-June precipitation variation for the upper Irtysh River Basin in the last 291 years.
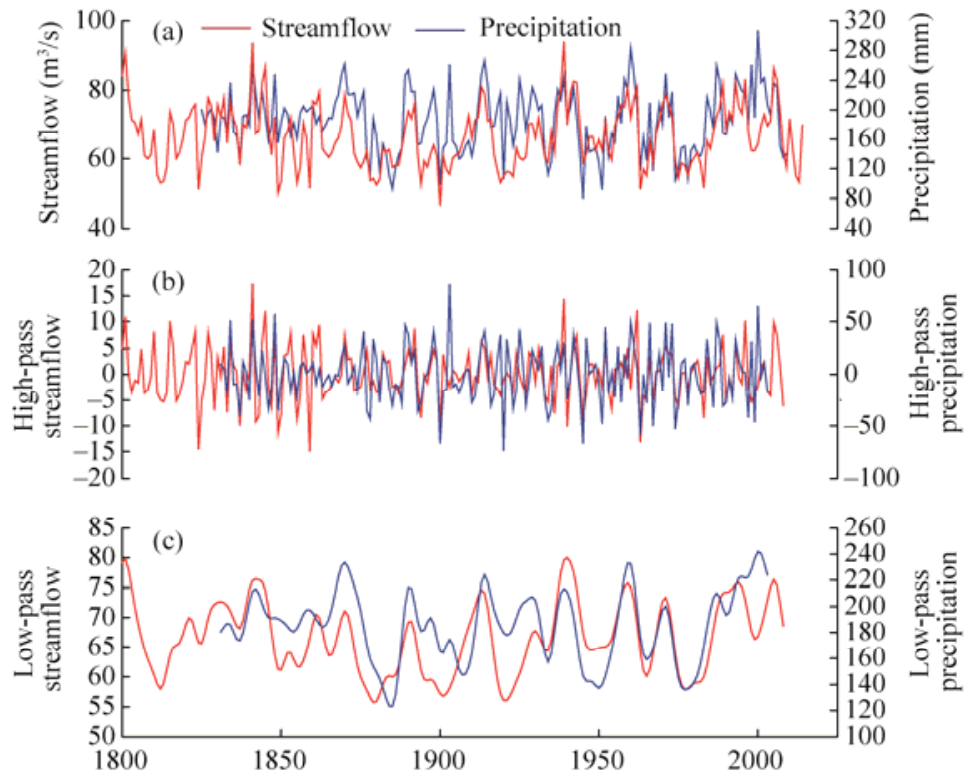

Fig. 8 Comparison of the streamflow reconstruction for the Haba River and the precipitation reconstruction for the Altay Mountains using 13-year reciprocal filters in the (a) original, (b) high-, and (c) low-frequency domains
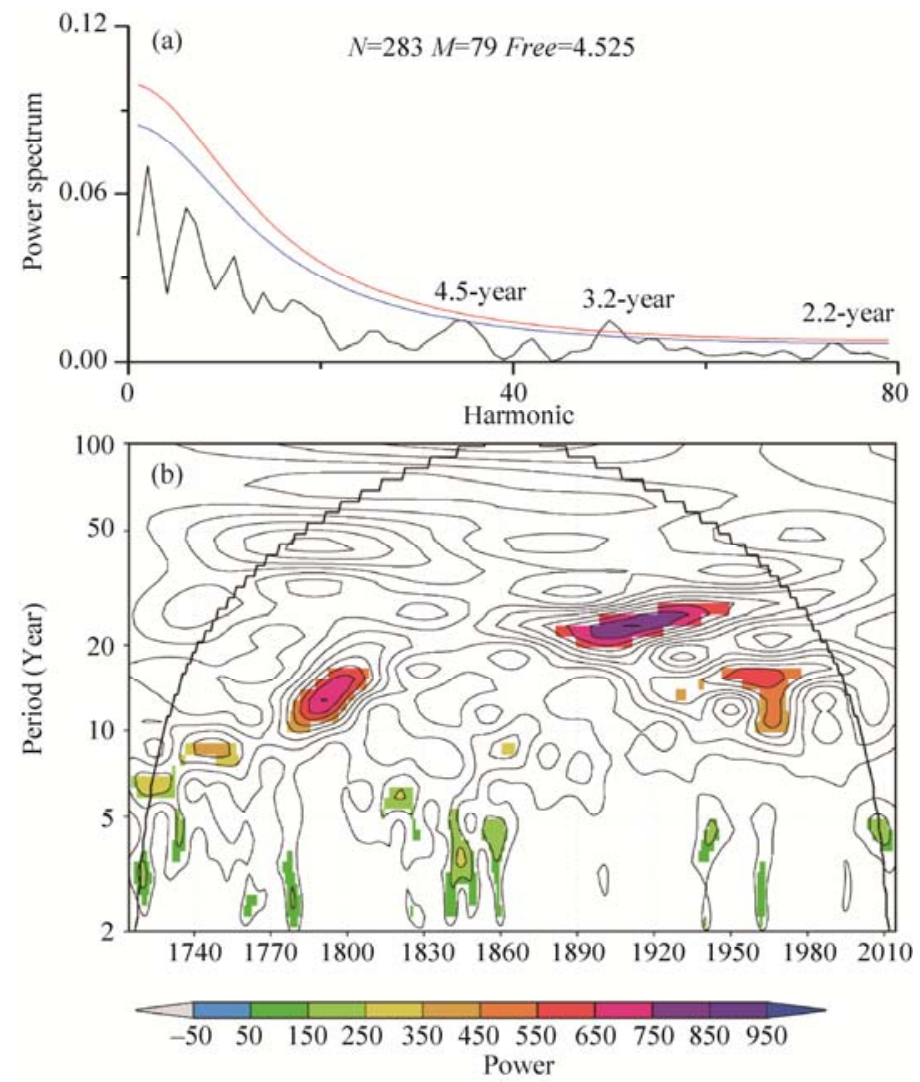

Fig. 9 Power spectrum (a) and wavelet power spectrum (b) of the reconstructed streamflow series for the Haba River. The blue line represents the $90 \%$ confidence level, and the red line represents the $95 \%$ confidence level. 


\section{Conclusions}

A 301-year long regional composite tree-ring width chronology was developed from 32 larch and 52 spruce trees sampled from three sites in the Haba River watershed. Because there was a high correlation coefficient between instrument-based hydrological data and the radial growth of sampling trees, it was possible to develop an annual streamflow reconstruction (from preceding July to succeeding June) for the Haba River using the regional composite chronology. The reconstruction matched the observed data well, and precisely captured flood and drought events occurring in 1776, 1900, 1963, 1983, and 1996 mentioned in the meteorological records and other tree-ring based hydro-climatic reconstructions. The $19^{\text {th }}$ century had the 4 wettest and 6 driest years, and the 3 wettest and 5 driest decades, and had the largest hydrological fluctuations for the target river in the last three centuries. After applying a 21-year moving average, five wet periods occurred during the periods 1724-1758, 1780-1810, 1822-1853, 1931-1967, and 1986-2004, while four periods $1759-1779,1811-1821,1854-1930$, and 1968-1985 were relatively dry in the low-frequency domain. Furthermore, four obvious increasing trend periods (1770-1796, 1816-1836, 1884-1949, and 1973-1997) were found in the reconstruction. The period since the 1970s has changed more dramatically than any other period in the last 300 years as a response to the recent warming-wetting trend for the northwestern China. The spatial correlations between the streamflow reconstruction and the gridded PDSI dataset revealed a significant positive correlation in the area of the northern Junggar Basin and the entire Altay Mountains. The significant correlation between our streamflow reconstruction and a precipitation reconstruction for the Altay Mountains in the original, high-, and low-frequency domains indicated that the streamflow reconstruction contained not only local but also broad-scale hydro-climatic signals. The 24-, 12-, and 2.2-4.5-year cycles in the reconstruction suggested that the streamflow variability of the Haba River may be influenced by solar activity and the atmosphere-ocean system.

\section{Acknowledgments}

This research was supported by the National Natural Science Foundation of China (41275120, 41605047), the Shanghai Cooperation Organization Science and Technology Partnership (2017E01032), the Special Foundation for Asian Regional Cooperation (Climate Reconstruction of Tian Shan in China, Kyrgyzstan and Tajikistan), and the Autonomous Region Youth Science and Technology Innovation Talents Training Project (qn2015bs025). We thank SHANG Huaming, HU Yicheng, NIU Junqiang, and LI Moyan for their great help in the process of collecting samples. Particular thanks are extended to the anonymous reviewers and editors whose comments and suggestion greatly benefited this manuscript.

\section{References}

Allan R, Lindesay J, Parker D. 1996. El Nino: Southern Oscillation and Climatic Variability. Collinwood: CSIRO Publishing, $1-23$.

Bai S Z, Li H, Zhang L M. 2014. Variation characteristics of precipitation in winter in Altay area. Desert and Oasis Meteorology, 8(1): 17-22. (in Chinese)

Bao G, Liu Y, Liu N. 2012. A tree-ring-based reconstruction of the Yimin River annual runoff in the Hulun Buir region, Inner Mongolia, for the past 135 years. Chinese Science Bulletin, 57(36): 4765-4775.

Chen F, Yuan Y J, Wei W S, et al. 2014. Precipitation reconstruction for the southern Altay Mountains (China) from tree rings of Siberian spruce, reveals recent wetting trend. Dendrochronologia, 32(3): 266-272.

Chen F, Yuan Y J, Zhang T W, et al. 2015. Long-term drought severity variations in the northern Altay Mountains and its linkages to the Irtysh River streamflow variability. Journal of Arid Land Resources and Environment, 29(8): 93-98. (in Chinese)

Chen F, Yuan Y J, Davi N, et al. 2016. Upper Irtysh River flow since AD 1500 as reconstructed by tree rings, reveals the hydroclimatic signal of inner Asia. Climatic Change, 139(3-4): 651-665.

Chen L F, Wang H Y. 2004. Sensitivity of runoff to climate change in small drainage basins in China. Resources Science, 26(6): 62-68. (in Chinese) 
Cook E R. 1985. A time-series analysis approach to tree-ring standardization. PhD Dissertation. Tucson: The University of Arizona.

Cook E R, Kairiukstis L A. 1990. Methods of Dendrochronology: Applications in the Environmental Sciences. Dordrecht, The Netherlands: Kluwer Academic Publishers, 97-162.

Cook E R, Meko D M, Stahle D W, et al. 1999. Drought reconstructions for the continental United States. Journal of Climate, 12(4): $1145-1162$.

Cook E R, Krusic P J. 2005. Program ARSTAN, A Tree-Ring Standardization Program Based on Detrending and Autoregressive Time Series Modeling, with Interactive Graphics. New York: Tree-Ring Laboratory Lamont Doherty Earth Observatory of Columbia University.

Dai A G, Trenberth K E, Qian T T. 2004. A global dataset of Palmer Drought Severity Index for 1870-2002: relationship with soil moisture and effects of surface warming. Journal of Hydrometeorology, 5(6): 1117-1130.

Devineni N, Lall U, Pederson N, et al. 2013. A tree-ring-based reconstruction of Delaware River basin streamflow using hierarchical Bayesian regression. Journal of Climate, 26(12): 4357-4374.

FAO, IIASA, ISRIC, et al. 2012. Harmonized World Soil Database (version 1.2). Rome, Italy: FAO.

Fritts H C. 1976. Tree Rings and Climate. London: Academic Press, 567.

Gou X H, Chen F H, Cook E, et al. 2007. Streamflow variations of the Yellow River over the past 593 years in western China reconstructed from tree rings. Water Resources Research, 43(6): W06434.

Grissino-Mayer H D. 2001. Evaluating crossdating accuracy: a manual and tutorial for the computer program COFECHA. Tree-Ring Research, 57(2): 205-221.

Jiang S X, Yuan Y J, Chen F, et al. 2016. A 291 year precipitation reconstruction in the upper Irtysh River basin based on tree-ring width. Acta Ecologica Sinica, 36(10): 2866-2875. (in Chinese)

Lara A, Villalba R, Urrutia R. 2008. A 400-year tree-ring record of the Puelo River summer-fall streamflow in the Valdivian rainforest eco-region, Chile. Climatic Change, 86(3-4): 331-356.

Li J F. 1989. Dendroclimatology and Dendrohydrology Research in Xinjiang. Beijing: Meteorological Publishers, 1-192. (in Chinese)

Li S, Li X Y, He Q, et al. 2006. Study on climate change in Altay prefecture since recent 40 years. Arid Zone Research, 23(4): 637-643. (in Chinese)

Li Z, Jiang F Q. 2007. A study of abrupt climate change in Xinjiang region during 1961-2004. Journal of Glaciology and Geocryology, 29(3): 351-359. (in Chinese)

Liang E Y, Liu X H, Yuan Y J, et al. 2006. The 1920s drought recorded by tree rings and historical documents in the semi-arid and arid areas of northern China. Climatic Change, 79(3-4): 403-432.

Liu L C. 1997. Genetic characteristics of soils under coniferous forest in north western part of Altai Mountains. Acta Pedologica Sinica, 34(3): 263-271. (in Chinese)

Liu Y, Sun J Y, Song H M, et al. 2010. Tree-ring hydrologic reconstructions for the Heihe River watershed, western China since AD 1430. Water Research, 44(9): 2781-2792.

Liu Y, Zhang Y, Song H, et al. 2014. Tree-ring reconstruction of seasonal mean minimum temperature at Mt. Yaoshan, China, since 1873 and its relevance to 20th-century warming. Climate of the Past, 10(2): 859-894.

Luo Z X. 2005. Introduction to Arid Climate Dynamics in Northwest China. Beijing: China Meteorological Press, 1-225. (in Chinese)

Maxwell R S, Hessl A E, Cook E R, et al. 2011. A multispecies tree ring reconstruction of Potomac River streamflow (950-2001). Water Resources Research, 47(5): W05512.

Michaelsen J. 1987. Cross-validation in statistical climate forecast models. Journal of Applied Meteorology, 26(11): 1589-1600.

Nagovitsyn Y A. 1997. A nonlinear mathematical model for the solar cyclicity and prospects for reconstructing the solar activity in the past. Astronomy Letters, 23(6): 742-748.

Osborn T J, Briffa K R, Jones P D. 1997. Adjusting variance for sample-size in tree-ring chronologies and other regional mean timeseries. Dendrochronologia, 15: 89-99.

Pederson N, Jacoby G, D'arrigo R D, et al. 2001. Hydrometeorological reconstructions for northeastern Mongolia derived from tree rings: 1651-1995. Journal of Climate, 14(5): 872-881.

Pimentel D, Berger B, Filiberto D, et al. 2004. Water resources: agricultural and environmental issues. BioScience, 54(10): 909-918.

Polacek D, Kofler W, Oberhuber W. 2006. Radial growth of Pinus sylvestris growing on alluvial terraces is sensitive to water-level fluctuations. New Phytologist, 169(2): 299-308.

Shah S K, Bhattacharyya A, Chaudhary V. 2014. Streamflow reconstruction of Eastern Himalaya River, Lachen 'Chhu', North 
Sikkim, based on tree-ring data of Larix griffithiana from Zemu Glacier basin. Dendrochronologia, 32(2): 97-106.

Shang H M, Wei W S, Yuan Y J, et al. 2011. Early summer temperature history in northeastern Kazakhstan during the last 310 years recorded by tree rings. Journal of Mountain Science, 29(4): 402-408. (in Chinese)

Shi F C, Wang G A, Gao Z D, et al. 1991. Recurrence probability of 11-year continuous low water period (1922 1932 A.D.) in the Yellow River. Advances in Water Science, 2(4): 258-263. (in Chinese)

Shi Y F, Shen Y P, Kang E S, et al. 2007. Recent and future climate change in northwest China. Climatic Change, 80(3-4): 379-393.

Siegfried T, Bernauer T, Guiennet R, et al. 2012. Will climate change exacerbate water stress in Central Asia? Climate Chang, 112(3-4): 881-899.

Speer J H. 2010. Fundamentals of Tree-ring Research. Tucson: The University of Arizona Press, 87-105.

Sun J Y, Liu Y, Wang Y C, et al. 2013. Tree-ring based runoff reconstruction of the upper Fenhe River basin, North China, since 1799 AD. Quaternary International, 283: 117-124.

Wells N, Goddard S, Hayes M J. 2004. A self-calibrating palmer drought severity index. Journal of Climate, 17(12): 2335-2351.

Wen K G, Shi Y G. 2006. The Documents of Chinese Meteorological Disaster: Volume of Xinjiang. Beijing: Meteorological Publishers, 4-146. (in Chinese)

Wigley T M L, Briffa K R, Jones P D. 1984. On the average value of correlated time series, with applications in dendroclimatology and hydrometeorology. Journal of Climate and Applied Meteorology, 23(2): 201-213.

Woodhouse C A. 2001. A tree-ring reconstruction of streamflow for the Colorado Front Range. Journal of the American Water Resources Association, 37(3): 561-569.

Woodhouse C A. 2003. A 431-yr reconstruction of Western Colorado Snowpack from tree rings. Journal of Climate, 16(10): $1551-1561$.

Yang B, Qin C, Shi F, et al. 2011. Tree ring-based annual streamflow reconstruction for the Heihe River in arid northwestern China from AD 575 and its implications for water resource management. The Holocene, 22(7): 773-784.

Yao T D, Wang Y Q, Liu S Y, et al. 2004. Recent glacial retreat in high Asia in China and its impact on water resource in Northwest China. Science in China Series D: Earth Sciences, 47(12): 1065-1075.

Young G A. 1994. Bootstrap: more than a stab in the dark? Statistical Science, 9(3): 382-415.

Yuan Y J, Shao X M, Wei W S, et al. 2007. The potential to reconstruct Manasi River streamflow in the northern Tien Shan Mountains (NW China). Tree-Ring Research, 63(2): 81-93.

Yuan Y J, Zhang T W, Wei W S, et al. 2013. Development of tree-ring maximum latewood density chronologies for the western Tien Shan Mountains, China: Influence of detrending method and climate response. Dendrochronologia, 31(3): $192-197$.

Zhang R B, Shang H M, Yuan Y J, et al. 2015a. Summer precipitation variation in the southern slope of the Altay Mountains recorded by tree-ring $\delta^{13} \mathrm{C}$. Journal of Desert Research, 35(1): 106-112. (in Chinese)

Zhang T W, Yuan Y J, Hu Y C, et al. 2015b. Early summer temperature changes in the southern Altai Mountains of Central Asia during the past 300 years. Quaternary International, 358: 68-76. 